\title{
Neoliberalism's Market Morality and Heteroflexibility: Protectionist and Free Market Discourses in Debates for Legal Prostitution
}

\author{
Barbara G. Brents \\ University of Nevada, Las Vegas, barb.brents@unlv.edu
}

Follow this and additional works at: https://digitalscholarship.unlv.edu/sociology_pubs

Part of the Gender and Sexuality Commons, and the Social Policy Commons

\section{Repository Citation \\ Brents, B. G. (2016). Neoliberalism's Market Morality and Heteroflexibility: Protectionist and Free Market Discourses in Debates for Legal Prostitution. Sexuality Research and Social Policy 1-15. Springer Verlag. https://digitalscholarship.unlv.edu/sociology_pubs/101}

This Postprint is protected by copyright and/or related rights. It has been brought to you by Digital Scholarship@UNLV with permission from the rights-holder(s). You are free to use this Postprint in any way that is permitted by the copyright and related rights legislation that applies to your use. For other uses you need to obtain permission from the rights-holder(s) directly, unless additional rights are indicated by a Creative Commons license in the record and/or on the work itself.

This Postprint has been accepted for inclusion in Sociology Faculty Publications by an authorized administrator of Digital Scholarship@UNLV. For more information, please contact digitalscholarship@unlv.edu. 


\title{
Neoliberalism's market morality and heteroflexibility: Protectionist and free market discourses in debates for legal prostitution
}

\author{
Barbara G. Brents \\ Department of Sociology, University of Nevada, Las Vegas, 89154-5033 \\ barb.brents@unlv.edu
}

\begin{abstract}
In August of 1999, not too long before narratives of sex trafficking began to dominate prostitution policy debates, the residents of a small town in Nevada debated closing the city's legal brothels. Citizens crowded the hearing hall, holding signs about protecting family and community values. But instead of opposing prostitution, as one might have expected, most public commenters echoed a sign that read, "Pro Family, Pro Prostitution." Drawing on an analysis of the testimony of the 51 citizens in attendance at that public hearing and ethnographic data gathered in four visits to Evenheart over a one-year period, this paper examines the arguments that framed support for, and opposition to, legal prostitution at this critical historic juncture. The research finds important differences in the ways particular neoliberal discourses can be deployed to the wide range of sexual, gender, and relationship values that constitute heterosexuality. Both supporters and opponents drew on market logics defined for purposes of this paper as a neoliberal individualism and economic rationality of free trade, scarcity, competition, and self-regulation - as well as on discourses of morality and the family, but each side used them in strikingly different ways. Brothel supporters drew on market logics to defend and support individualized family values and a marketdriven morality, while brothel opponents deployed market logics that supported conservative heteronormative values and morals. I suggest that these deployments of market logics, particularly among brothel supporters, are instances of "heteroflexibility" in neoliberal governance, that is, flexibility in the various gender, sexual, and relationship norms that collectively make up heterosexuality as an institution. Key to the intensity of heteroflexibility's challenge to heterosexuality, both then and today, is whether market logics use free choice or protection discourses in the neoliberal governance of sexuality.
\end{abstract}

In June of 1999 a young Mormon city councilman in rural Evenheart ${ }^{1}$, Nevada introduced an ordinance aimed at closing the city's legal brothels. The ensuing debate split the community, upsetting the balance of religion and sexuality that allowed legal brothels to exist there into the $20^{\text {th }}$ century.

\footnotetext{
${ }^{1}$ Evenheart is a fictitious name.
}

That August, the City Council moved out of their usual meeting space at the fire hall in order to accommodate the nearly 300 (of 4,000 total) residents seeking to attend the public hearing. Fifty-one speakers testified. Mothers trotted out their children next to riled up little old ladies, all demanding the recognition and privileging of family values and calling for protection of the town's moral fiber. But the vast majority of these folks weren't speaking against prostitution. They were speaking for it. In the end, the ordinance was defeated and the brothels remain legal.

What does the debate in rural Nevada nearly 20 years ago reveal about sexual politics both then and today, occurring as it did near a turning point for prostitution politics in the United States? Beginning in the 1970s, a neoliberal ideology of individual choice and free markets, a growing trend of sexually liberal attitudes, sex positive feminism, and a mainstreaming sex industry allowed sex worker rights movements to make significant gains. A number of countries around the world decriminalized prostitution during the late 1970s and 1980s, including the Netherlands and parts of Australia (Brents \& Sanders, 2010; S. Jackson \& Scott, 2004; Kelly, 2008; Outshoorn, 2004; Weitzer, 2011; Wonders \& Michalowski, 2001). Public tolerance for prostitution had been increasing in Western democracies since the 1980s (Burke, 2014; Cao, Lu, \& Mei, 2015; Cao \& Maguire, 2013; Inglehart \& Norris, 2003; Stack, Adamczyk, \& Cao, 2010; Weitzer, 2015). Even anti-prostitution advocates believed there was little social resistance to legalizing prostitution through much of the 1990s (Coalition Against Trafficking in Women, 2011).

Since the early 2000s, though, there has been a significant shift in prostitution politics and discourse. Fueled largely by a moral panic that conflated prostitution and sex trafficking, prostitution began to see increased criminalization in the United States and across Europe. Scholars analyzing antitrafficking policies and debates argue that these, too, are grounded in neoliberal discourse, in particular a protectionist discourse that empowers criminal justice institutions to police poor communities and minorities in order to protect women from being trafficked - but only self-advancing women who conform to ideals of relational heterosexuality and middle class femininity (Bernstein, 2012; Cheng \& Kim, 2014; Kempadoo, 2005; Lerum \& Brents, 2016; Sanders \& Campbell, 2014). 
How can both supporting and opposing discourses in today's prostitution debates be seen in the context of neoliberal governance? The majority of studies of sexual politics find that neoliberalism generally reproduces ultimately conservative and heteronormative moral, sexual, and relationship values (Bernstein, 2012; Duggan, 2004), a finding that by itself would not necessarily explain the 1970s-1990s trends toward a more mainstream sex industry, sex worker rights, and decriminalized prostitution. Recent studies find plenty of variability, contradiction, and historical change in neoliberal governance. While beginning with more free market discourses, the $21^{\text {st }}$ century has taken a punitive turn that has re-regulated marginalized groups under the marketdriven logic of protecting appropriately self-managing (and privileged) neoliberal citizens (Peck, Theodore, \& Brenner, 2010; Peck \& Tickell, 2002; Soss, Fording, \& Schram, 2011; Wacquant, 2009). This protectionist discourse may explain the increased vigor for the criminalization of prostitution in recent years, but few studies have examined specific market logics and how they may be differently deployed in the debate. Local and regional accounts can offer more insight into the contextual and historically variable character of neoliberal governance, as well as show how different discourses may be differently adopted (Ong, 2006; Peck et al., 2010).

The body of Nevada laws that legalized prostitution in the 1970s can be read as part of a neoliberal turn, and part and parcel of the sex industry's expansion in the United States as courts rejected public nuisance and obscenity cases on free speech grounds. Nevada's legal prostitution stems from free choice, libertarian, and individualist ideologies grounded in a service/tourist economy (Bowers, 1996; Brents, Jackson, \& Hausbeck, 2010; Moehring, 2000). Additionally and more broadly, Nevada's brothel laws are an extension of turn of the century social order laws - red light zones and worker health testing policies that were common in the West until World War II (Brents \& Hausbeck, 2001; Brents et al., 2010; Hausbeck \& Brents, 2009a).

Many of the social order discourses that informed the development of prostitution policies even into the twentieth century had a more collective focus, though, seeking to protect the community from the destabilizing effects of visible deviance and disease (Gilfoyle, 1992; Hennigan, 2004; Lucas, 1995). This is very different than prostitution policy discourses that regulated individual behavior through moral and protectionist discourses, i.e. discourses defining prostitutes as either victims or fallen women (Brents \& Sanders, 2016 (in press); Kantola \& Squires, 2004; Luker, 1998; Weitzer, 2009). The Evenheart debate in 1999 provides important data from which to analyze attitudes toward sexuality, gender, morality, relationships, and the logic of the market (individualized citizenship, both free choice and protectionist) and how these may diverge, or not, from social order, gender inequality, or other prostitution discourses at a key moment in history.

This paper examines the arguments that framed both support for and opposition to legal prostitution through a close analysis of citizen testimony at the public hearing debating the ordinance to close the legal brothels, as well as through ethnographic data gathered in four visits to Evenheart in the year surrounding the event. I find that market logics could be deployed quite differently in the debate, and that some of these deployments challenge some heteronormative sexual, moral, and relationship values.

In Evenheart, neoliberal market logics (defined here as an economic rationality of free trade, scarcity, competition, and individual self-regulation) were used to both oppose and support prostitution. Likewise, both sides drew on discourses of morality and family. The juxtaposition of neoliberal discourse and market logics on both the "pro" and "con" side of the debate reveal two important points. First, brothel opponents drew on market logics that reinforced conservative morality and heterosexual family values, while brothel supporters constructed a morality and set of family values that drew on a logic of the market that leaves room for greater diversity in sexual values. The sexual values of the supporters legitimized previously marginalized sexual groups, as long as these citizens were also sufficiently self-advancing and selfsufficient. Second, and importantly, both brothel supporters and opponents enlisted free choice and protectionist discourses, and it was these protectionist discourses that reinforced heteronormative gender values.

At least in this localized example, market logics sustained class values and both reproduced and challenged some of the variety of norms that have built the dominance of heterosexual institutions. I therefore suggest that sexual discourses in neoliberal culture are best seen as "heteroflexible," that is, showing flexibility in the wide range of gender, sexuality, and relationship norms that make up heterosexuality. This heteroflexibility can both sustain and potentially challenge the ubiquity of heterosexuality by granting rights to previously excluded groups. Key to the challenge is how discourses of protection and free choice are deployed in sexual discourses, and how and whether those specific discourses become more widely enlisted in modern neoliberal thought.

\section{Neoliberalism, sex, and prostitution}

While largely used for characterizing economic policy that since the 1970s has promoted individual responsibility, free choice, free markets, commodification, and deregulation (Duggan, 2004; Harvey, 2007), the term neoliberalism is also treated as a form of governance. Its practices, though uneven and contradictory, have a cumulative effect that extends the logic, imagination, discourse, and epistemology of the market to social relations, culture, and constructions of personhood (Foucault, 1978; Shamir, 2008). Neoliberal market logics transform social belonging from the collective to "radically individuated citizenship" (Lemke, 2001; Miller, Gordon, \& Burchell, 1991; Sparke, 2006, p. 155). Citizenship in this logic is less oriented to vesting oneself in a community and is instead predicated on becoming a self-regulating, selfsufficient, self-enhancing, entrepreneurial consumer. Equality and diversity are valued as market-granted individual traits at the same time that class inequality is overlooked. The recent punitive turn adds a discourse of protection to free choice discourses, monitoring and controlling insufficiently self- 
enhancing citizens less to protect community social order (as in previous eras) and more for their own good as well as to protect "good" individual citizens (Duggan, 2004; Ferguson, 2012; Grzanka \& Maher, 2012).

Just how this neoliberal governance extends to sexual politics has been the subject of scholarly debate. Enjoyment of sexual desire, tolerance for women's sexual agency, extramarital sex, homosexuality, divorce, teen sex, and abortion, as well as increased support for gender equality, all seemingly challenge traditional heteronormative sexualities and moralities in neoliberal regimes in Western Europe, North America, and Australia (Inglehart, 1990, 1997, 2008; Inglehart $\&$ Norris, 2003; Stack et al., 2010). Since the 1960s, discourses of individual freedom of choice and expression have helped dismantle many anti-obscenity, sodomy, and antipornography laws that once constrained sexual behavior and consumption. While reproducing market driven inequality, a mainstreaming sex industry and increasing availability of a broad array of sexual services brings private intimacy to market, celebrates and commodifies sexual pleasure, normalizes temporary relationships, and expands or at least shifts the range of acceptable and normative sexual identities and practices (Attwood, 2006; Bauman, 2003; Bernstein, 2001, 2007b; Brents \& Sanders, 2010; Hausbeck \& Brents, 2009b; Illouz, 1997; Plummer, 2003; Rubin, 1984; Zelizer, 2005).

Despite these liberalizing trends, a number of scholars highlight that neoliberal governance consistently excludes anyone not labeled self-advancing and heteronormatively coupled, domestic, gendered, and sexual (Bernstein, 2012; Duggan, 2004). Heterosexuality and its underlying moral system are reproduced in IMF and World Bank lending policies to Third World countries (Bedford, 2009), gay and lesbian policy, including even marriage rights (Butler, 2008; Duggan, 2004; Heath, 2012, 2013; Wilson, 2015), sex education policy (Elliott, 2014), and even in anti-GLBT suicide campaigns (Grzanka \& Mann, 2014, p. 387). Even new-found sexual agency in young women is little more than a pretext as policies reproduce middle class femininity and male hyper heterosexuality, especially in groups already marginalized by race and class (Bay-Cheng, 2015; Elliott, 2014).

Neoliberal governance also appears to facilitate a conservative moral agenda, especially in recent prostitution policies. A Christian right/conservative political coalition marshaled neoliberal protectionist discourse in passing antitrafficking policy that increased surveillance of immigrants and minorities in the service of protecting middle class, appropriately heterosexual women's rights (Bernstein, 2007a; Bernstein \& Jakobsen, 2010; Chapkis, 2003; Weitzer, 2007). The guise of amorality possible in neoliberal discourse offers cover to a conservative religious moral agenda often concealed in sex trafficking state apparatus across the globe (Cheng \& Kim, 2014).

If some sexuality research finds that market logics reproduce heteronormative moral, sexual and relationship values, other research finds neoliberal logics to be contextdependent and in some cases counter-hegemonic (Brenner,
Peck, \& Theodore, 2010; Ong, 2006; Peck et al., 2010). Studies of HIV policies for sex workers and sex positive sex toy stores find that elements of neoliberalism can be rearticulated and marshaled to challenge the sexual status quo, expanding political space for citizenship rights to previously marginalized groups (Comella, 2012; Lakkimsetti, 2014; Rivers-Moore, 2014).

While moral discourse plays heavily in sexuality policy, and especially in debates on prostitution, scholarship on morality in neoliberalism generally finds that it can be reshaped in the logic of the market (Shamir, 2008). Neoliberal discourses reflect a belief in the moral superiority of individual free choice and expression - individual autonomy, a rejection of social status distinctions, tolerance, and the democratic equality (at least in theory) of contract based commodity exchange - as a guiding human value (Bauman, 2000; Harvey, 2007). Free choice market logics appear to foster a normative acceptance of diverse lifestyles and previously marginalized groups, at least those that may expand consumer markets or are sufficiently self-advancing (Bernstein, 2001; Harvey, 1989; Hawkes, 1996; Prasad, 1999). This "market morality" also justifies and values pleasure, eroticism, and intimacy, albeit as a commodity in the leisure industry, legitimating a "desiring" citizen-consumer (Rofel, 2007). Studies show that male customers of sex workers draw on this "market morality" consisting of values centered on "autonomy, democratic equality, and unambiguous and nondiscretionary fulfillment of obligations" (Prasad, 1999, p. 185), "bounded authenticity" (Bernstein, 2007b) or "deserving consumers" (Pettinger, 2013) to justify the superiority of prostitution over the gift exchange inherent in relational sex. Valuing this sexually desiring subject also contrasts the value of asceticism in western Christianity (Hawkes, 1996); it also sits in contrast to a softened but remaining ambiguity toward sexual desire in contemporary religion (Burke, 2014).

Is there another construct through which to understand neoliberal governance's impact on sexual politics, as well as corresponding challenges to heteronormative moral, sexual, and relationship discourses? While heterosexual behaviors have largely been the norm throughout much human history, heterosexuality as the dominant sexual institution has had a relatively short history, achieving supremacy in its current form during modern industrial capitalism (Katz, 2014, p. 14; White, 1993). Heterosexuality's ascendance rested on a particular array of elements regarding the arrangement of genders, pleasures, and relationships that went beyond just erotic attraction to the opposite sex, including bifurcated and fixed conceptions of gender, norms of sexually active males and passive females, monogamous coupledom, the patriarchal family, the primacy of relational over recreational sex, the asexuality of youth, anxiety around public expressions of sex, sexual pleasure as dangerous, and the value of sexual asceticism (Hawkes, 1996). Recent imperatives of consumption have challenged modernity's rational ordering of irrational sexual desires. Gail Hawkes (1996) argues that in the consumer based political economy of the late twentieth century, the dissolution of fixed bonds between gender, sexual 
identity, and sexual desire are exposing important fault lines in heterosexuality such that we are posed with the question,

"Can we, at the close of the twentieth century, now lay claim to a new sexual orthodoxy, one which derives from the context of late modernity - an orthodoxy which reflects the lack of fixity in social categories, and the emergence of reflexivity as the integument between the individual and the social?" (p. 4)

I draw from Hawkes' questioning of the heterosexual orthodoxy at the century's turn to investigate other fault lines in heterosexuality's dominance that have since widened. Heterosexuality in today's neoliberal culture now conditionally includes same-sex monogamous coupledom, sexual agency of women, guilt-infused sexual agency of teens, as well as certain consumers' rights to intimacy purchased on the public market, evidencing a certain variable amount of flexibility that tests the ubiquitous character of heterosexuality as an institution. While these echo flexibilty in pre-industrial times, it is worth investigating how market logics may affect a re-emerging flexibility. Building on earlier theorizations of heteroflexibility which largely have been identity-based in focusing on the behavior of heterosexual females engaging in same sex intimacy (Ambrose, 2009; Frohard-Dourlent, 2012; Read, 2013), I suggest that heteroflexibility is also a useful concept to make sense of flexibility in the wide range of gender, sexuality, and relationship norms, ideologies and discourses that have both sustained and undermined heterosexuality's dominance as an institution in neoliberalism. This heteroflexibility in the wide array of norms may or may not constitute a "new" sexual orthodoxy, but it certainly poses challenges. In this study, I will investigate the ways in which market logics are deployed in discourses of morality, the family, gender, and sexuality, and the specific elements in this dialogue that may and may not contribute toward heteroflexibility in neoliberal governance.

\section{Data and Methods}

This paper is based primarily on a content analysis of the arguments presented at a public hearing held on August 26, 1999 on an ordinance (City Council Ordinance \#407) to eradicate legal brothels in Evenheart, Nevada. Nevada is the only state in the United States with legal prostitution in licensed brothels; they operate in a few rural counties. In spite of the fact that Mormons initially settled the state and substantially influenced its politics well into the 1990s, the state built an economy from legalizing gambling and vice. Its free choice, free market, pro-pleasure culture coexisted with strong religious values, making it a good location to explore complexities in citizen political discourses about sexuality and

Those speaking in favor of legal brothels based their support most often on themes of community cohesion, the belief that legal brothels contributed to social order, the fact that brothels had economic benefits, and the belief that people had a right to believe and do whatever they wanted to do. Those speaking against the brothels most often justified their the market (Bowers, 1996; Brents et al., 2010; Moehring, 2000).

At the time of the hearing, I and another researcher were in the midst of what became ten years of qualitative fieldwork on Nevada's sex industry and its brothel system (Brents et al., 2010). As the issue emerged earlier that spring, my colleague and I were called by local ACLU representatives as well as by the Evenheart mayor's office to offer our thoughts on the issues, and eventually we were asked to testify at the hearings. In this paper, then, I draw on relevant ethnographic notes, historical and contemporary documents, newspaper articles, and secondary materials from the larger research project to help contextualize the debates in the testimony. In addition to analysis of the testimony, I draw on ethnographic data my colleague and I collected in four visits to Evenheart over a one-year period before and after the hearing. During these visits we interviewed brothel owners and managers and spoke informally with townspeople at local restaurants, bars, and at the various public hearings. I also examined newspaper articles on the brothel and relatedl issues that were published that summer.

After the hearing, we obtained transcripts from the city office and I analyzed the testimony of the 51 individuals who spoke at the hearing (not including myself and my colleague) for the ways in support or opposition to the legal brothels was framed. Most of the speakers identified themselves as local residents. There were a very few out of town speakers, including the brothel association lobbyist, an attorney for the brothel, and a few businessmen operating in the area. Individuals who testified gave no additional identifying information other than what they said during their testimony. All individuals' names are pseudonyms.

I label as support or opposition whether they were testifying for or against legal brothels (not for or against the ordinance to close the brothels). There were two individuals who did not express an opinion either way. I then used a grounded approach to identify patterns in how individuals justified their support or opposition. I coded a number of discrete themes used as justifications for each individual who testified, and then grouped these into broader themes that cut across both support and opposition.

Of the 51 speakers coded at the hearing, 36 spoke in support of retaining the brothels, 13 opposed the brothels, and two did not directly state an opinion but rather issued a call for unity. I identified seven narrative themes that ran through both support and opposition. Table 1 summarizes the number of individuals mentioning major themes most often in their testimony for and against the brothels. In some cases, an individual had several different themes in his/her testimony, sometimes within one sentence. However, if an individual repeated the same theme within the scope of his/her testimony, this was counted as just one instance.

opposition based on themes of community cohesion, religious moral values, and the protection of families and children.

While some of these narratives on their face are similar to those found in previous research, what is more interesting is the ways these narratives interacted with each other and drew on market logics. In what follows, I offer a more in-depth 
Table 1 Individuals Speakers Who Mentioned Major Themes -Evenheart Brothel Debate

\begin{tabular}{|c|c|c|c|}
\hline Theme & $\begin{array}{l}\text { Total who } \\
\text { mentioned }\end{array}$ & $\begin{array}{l}\text { Number of } \\
\text { supporters } \\
\text { who } \\
\text { mentioned }\end{array}$ & $\begin{array}{l}\text { Number of } \\
\text { opponents } \\
\text { who } \\
\text { mentioned }\end{array}$ \\
\hline $\begin{array}{l}\text { Community -- references to } \\
\text { belonging, locale, place }\end{array}$ & 32 & 22 & 10 \\
\hline $\begin{array}{l}\text { Social Order - crime, } \\
\text { violence, safety, health, } \\
\text { indecency, disruption to } \\
\text { norms }\end{array}$ & 25 & 21 & 4 \\
\hline $\begin{array}{l}\text { Economy - business or } \\
\text { consumer interest, jobs, } \\
\text { profit }\end{array}$ & 24 & 19 & 5 \\
\hline $\begin{array}{l}\text { Morality - specific } \\
\text { reference to religion, or } \\
\text { religious context }\end{array}$ & 24 & 17 & 7 \\
\hline $\begin{array}{l}\text { Individual freedom - free } \\
\text { choice, tolerance }\end{array}$ & 21 & 20 & 1 \\
\hline $\begin{array}{l}\text { Family_references to } \\
\text { children \& family } \\
\text { values }\end{array}$ & 21 & 14 & 7 \\
\hline $\begin{array}{l}\text { Gender - references to } \\
\text { women, girls, men }\end{array}$ & 12 & 7 & 5 \\
\hline TOTAL SPEAKERS & $49 *$ & 36 & 13 \\
\hline
\end{tabular}

*This total omits two speakers who did not express an opinion on the proposed ordinance.

\section{Results}

\section{Social order}

That social order discourse was a major narrative theme was not surprising and was evidence that community-driven discourses were still important in Evenheart. I say "not surprising" because previous research finds that prostitution's relation to social disorder is one of the three main discourses in contemporary prostitution debates (social order, moral order, and gender inequality/women's rights - either supporting sex worker rights or opposing prostitute victimization) (Kantola \& Squires, 2004; Outshoorn, 2001; Symons \& Gillis, 2014; Weitzer, 2009). It has also been key to prostitution jurisprudence since the 1800 s (Kantola $\&$ Squires, 2004; Weitzer, 2009) and was key to regulation and zoning in the United States around the turn of the century (Best, 1998; Brents \& Sanders, 2016 (in press); Gilfoyle, 1992; Hennigan, 2004; Laite, 2011; Lucas, 1995).

Evenheart brothel supporters said, "This has been going on for some 30 years," and that brothels caused "no problems," "never bothered anybody," and were essentially invisible. Many commented that legal prostitution helped control crime, and brothel management had "more control there than you see downtown," referring to the sometimes illicit behavior of local men and women in downtown bars. Given that Nevada analysis of these broad themes, exploring their significance for their relation to neoliberal governance. In particular, I show how how market logics were deployed in varying ways in each of these narratives.

brothel workers are tested regularly for HIV and sexually transmitted diseases, a few proponents also claimed that brothels were safer than the alternative. (A few opponents argued that brothels did cause crime or that "safe sex is a myth.") While all of this social order discourse was oriented to the community's collective values, as I will discuss below, the debate in Evenheart was as much about diversity in individual values and what kind of individuals constituted that community as it was about how safe, disorderly, or criminal the brothels were.

\section{Community Citizenship and Market Logics}

Talk of "community" cohesion and belonging was the most common discourse used by both brothel opponents and supporters (32 instances vs. 25 discourses on social order, 24 morality or economy discourses, and 21 discourses based on either individual freedom or family). Both brothel supporters and opponents talked frequently about community cohesion, in part because of the divisive nature of the debate. Most speakers sought to establish their individual legitimacy in the community in relation to how long they had lived there, how well they knew the community, or how much they cared about the community. In addition, there was a lot of the talk about "who we are as a community" in reaction against the perceived stigma of being one of the few towns in the United States with legal prostitution. A subset of Nevada officials and citizens alike have been self-conscious about the brothels since they were legalized in the 1970s and defensive about a kind of "whore stigma" that they felt potentially made Nevada a national laughing stock (Brents et al., 2010).

However, testimony invoking community was deployed in varying ways, and provided a great deal of insight into the criteria for judging who were legitimate and illegitimate community members and how this interacted with market logics. To be sure, Evenheart's community talk clearly reflected the predominantly white, middle, or working class values and lifestyles of its mostly white citizens, and there was little overt talk of race or class. Both supporters and opponents sought to establish themselves as responsible and moral individuals. Both supporters and opponents used both their membership in a family and adherence to traditional family values as criterion of legitimacy. I discuss these below.

Morality and market logics

Also consistent with prior research on this topic was the enlistment of morality in testimony. Brothel opponents' moral arguments overall reflected traditional religious relationship and sexual values. Most brothel opponents testified simply that brothels were immoral and hence violated key community 
values. Opponents said brothels "teach immoral character to the community," "affects the youth of the community," and asked the city council to make law on a "moral ground" and "rid this community from this abhorrent evil." One opponent called prostitution "legalized evil" and during testimony chastised a man's "selfish urge" that would cause him to leave his wife, "pregnant with his child," to visit the brothel. These discourses drew on absolute notions of good and evil and deference to religious authority. They also reflected traditional heterosexual family and relationship values, parentchild ties, the asexuality of children, patriarchal gender norms, monogamy, and relationship (as opposed to recreational) sex. Additionally, they reflected key sexual values that also support heterosexuality - the inappropriateness of public sexuality, sexual restraint, and the need to control the body and desire.

Morality was also one of the most common themes enlisted in brothel support. Brothel supporters established a very different kind of morality from that of opposers, one reflecting a market logic - in short, a morality of individual rights, free choice, and individually morally-responsible citizens. Individual freedom and the idea that government ought not regulate private life is a common political theme in the Western United States (Bowers, 1996). Many brothel supporters drew on this tradition in defining their community's moral values.

Lynda: There is very little common sense except for a place like Nevada, where we have hoped to have tolerance and to live at peace in a very diverse culture. To me, it's the diversity of the culture and the tolerance, are the most important things we have. I don't like paying my taxes to support [nearby] schools where bigamy is practiced, but I do it, because I live in a community. I don't like paying my taxes to stand behind a parochial school, but I do it. It seems to me that the most important thing that we are addressing here is ... what Nevada is.

I discuss the use of family discourse further in the section below, but it is important to note that in establishing the importance of individual free choice in their private lives, Lynda also made sure to mention her family's presence in the community prior to this excerpt. Key to her testimony was the fact that she was a tax paying citizen and that she was tolerant of other religions and other family forms, including polygamy, which was reportedly practiced in neighboring communities.

Many supporters spoke of the ideas of freedom and tolerance as explicitly moral beliefs. In most all of these cases, the word "morality" accompanied discussions of tolerance, or not forcing personal beliefs on others. While a few speakers referred to the right to "do as you please" without using the term "morals," many supporters used religious language to criticize brothel opponents' conservative religious morality.

Gaspard: You have another choice, live and let live, do unto others, cast the first stone if you're not a sinner.

Abigail: But as much as I believe in Jesus, with all my heart, I thank God each day I have freedom of religion and I am an American and proud to be one. ... I thank
God for my founding fathers for the separation of church and state and allowing us choices. You can never come to know the Father unless you have chosen to follow Jesus, and that's a choice. It's not the role of government to make that choice for us.

This morality of individual choice defined them as good citizens in their own discourse, and one brothel supporter claimed legitimacy because she was a taxpayer and citizen in defending her freedom-of-choice morality.

Christie: As a taxpayer and citizen, I am one that does not believe in pushing my morals and beliefs and religion off on others. I will not stand in judgment of someone else who may have different views from me. What gives these so-called "good doers" the right to stand in judgment of me, because I don't care whether or not we have a brothel here? As far as I'm concerned, this is a bar and what goes on behind closed doors at this establishment is no one's business. But don't call me, my family, or my ancestors immoral because we don't feel there is a problem with having brothels open.

Both sides, then, sought to establish themselves as individually responsible moral citizens. Like many supporters, Christie above called out "good doers" for being bad, irresponsible individuals. In saying, "I don't want your morals shoved down my throat and I'm not going to shove mine down yours" as many did, morality was not a collective value, but personalized and individualized. One speaker, a local business owner, justified her belief not based on an appeal to collective morals or absolute rightness, but on whether she herself was a good person.

Margretta: I have been in this community for forty-six years, I have worked twenty years plus in public life, I believe that many of you know me and am I not a good person? But my philosophy again, is live and let live, and judge people as they are, not how you or I would want them to be.

Brothel supporters also cast morality as an individual (not community) character trait in their attack on the city councilman who introduced the ordinance. Supporters charged that he was an outsider (though he married into a long-time local family) trying to foist his view on the collective will of the town, not fully understanding local culture and politics. This personalized attack was relatively infrequent in testimony, but fairly frequent in private conversations. Some even accused this "newcomer" as perhaps being a front man for other Mormon businessmen from out of town who wanted the land on which the brothels sat.

Raina: Speaking for myself and my family, I feel more threatened by you and your people in this endeavor than those houses on High Street have ever affected me.

In this quote, the speaker's personal attack turned social control arguments from one centered on a threat to the community by the brothel houses to a threat from this 
individual "outsider" and his "people." The threat, in her view, was to the individual rights and freedoms of legitimate community members, establishing long time residents as having moral legitimacy. Her attack set up her opponents as outsiders and irresponsible citizens.

Protecting the individual's right to choose was also directly linked to the market, in keeping with the tenets of neoliberal market morality. Christie, quoted a few paragraphs above, as a "taxpayer and citizen" reflected a common justification for an individual's rights to sexual privacy in a public commercial establishment. Sydney, whose comments are included below, also proposed the idea that what some might consider immoral personally is okay if it is part of business.

Sydney: It's a business and they are not hurting anybody. You have to use your freedom of choice to go there to participate in these services.

Georgia: In any business, I don't care what it is, if you don't want to partake of that business, if you don't want services, simply don't go. They'll close on their own... If you want a certain business out, let the market take care of that.

Susan: It seems to me that this is a service industry. If you don't want to use them, nobody says you have to, but you have that right

Several speakers made reference to the idea that Nevada's tourist economy was built on this market morality, i.e. the right to buy and sell what some may consider immoral vices but were other individuals' pleasures, as long as they are not hurting anybody. Simon said it best.

Simon: Let's talk about gaming, 24-hour availability of liquor, quickie divorces, all the things we do here in Nevada. We have been very successful at this because we recognize one overriding issue, and that is that one man's morality is another man's pleasure. That what's immoral today, is accepted practice tomorrow. And that it's up to each individual to decide what he wants to be moral in life.

Again, the market logic or ideology was not just about one's privacy, but also about the right of businesses to serve whatever needs or desires individuals had, as long as they didn't hurt others. While not articulated as specifically sexual, Simon did say clearly that pleasure was a legitimate commodity and that it's rightness was rooted in the fact that it may be profitable. Referring to Nevada's gambling and liquor laws, Simon went on to say,

Simon: This is the way of the future. And for this town, this community, this county to start stepping backwards is going to have very serious economic implications.

Thus was morality espoused by many brothel supporters, reflecting a logic of the market, and in particular, discourses of free choice. Whatever an individual believes or desires is moral if there is a market for it, either in the marketplace of ideas, or if it is a profitable business and doesn't hurt anyone. Lynda's remark at the outset of this section about being tolerant of paying taxes to support parochial schools and schools where polygamy was practiced was evidence of the moral value of accepting diverse lifestyles. This free choice market logic reflected both individualized community values, and made the market the determinant of morality. While brothel opponents drew on traditional notions of morality, brothel supporters drew on a market morality that left room for diversity in sexual values.

\section{Family Values And Individual Responsibility}

Just as pro-brothel testimony sought to define and reclaim morality, it also sought to reclaim family values as consistent with legal brothels. Family values rhetoric had played frequently in public debates in the local newspapers in the weeks prior to the public hearing, and many brothel supporters in attendance at the public hearing defended themselves against "family values" talk used by more than half of those testifying against the brothels. Nearly $40 \%$ of speakers defended the brothels using talk of family values.

Brothel opponents testified that closing brothels would protect children from sexual amorality, specifically enforcing key heterosexual values such as the asexuality of children, as well as values of sexual restraint, the denial of desire, monogamy, and the primacy of relationship sex. But brothel supporters also linked their family values with protecting children.

Raina: It's a great community to raise children in, and that's over 80 years of being in this community raising children, making a living, and knowing that the houses on High Street exist.

Shellie: I've raised three children around the area, around the [two brothels]. My kids knew the girls; they were never hurt or anything else by them.

Many supporters addressed the stigma of being in a community with brothels by using family values to justify their view of themselves as "good" citizens.

Sydney: I take great offense when anybody says that perhaps I grew up a little bit warped because I grew up in [a nearby Nevada town] and brothels were legal. Or that because I raised five children in Evenheart, maybe they didn't grow up just right because they had stigmatism [sic] attached to them. This is ridiculous. I believe I raised a darn good family here in Evenheart and I don't think they lacked anything because you have brothels here in town.

Christie: In spite of what some people are claiming, we don't think Evenheart has to be ashamed of its sense of morality. We have lots of good people here that have brought up their families and are proud to call Evenheart their home.

Underlying this discussion of family values was a logic of individual responsibility. Protecting children was not the 
community's responsibility, but the individual family's responsibility, despite what may be going on around them.

Margretta: My main concern is the people, whoever they are, constantly talking about family values. I am concerned about family values also, but are the values so bad that you think it's going to hurt your children? Tell me, is everyone so insecure at the job that they have done as parents to not teach their children right from wrong, as to not let them be influenced by those kinds of morals?

In this set of remarks and in the rest of her short testimony, Margretta articulated a point underlying much of the family values testimony. Her point was that any individual family can competently raise children in any community as they see fit, regardless of surroundings. She believed it was a parent's responsibility to protect and educate their children. While this idea supports the importance of the traditional family, it also left room for the existence of heteroflexible relationship, sexual, and gender norms, as we will see more clearly below.

\section{Sex as Business - Good Consumers \& Good Workers}

While market logic was frequently woven into talk of morality and family values, much of the testimony also directly debated the economic value of brothels as businesses and the value (or lack thereof) of customers and clients they brought into the area. At the time of the hearing, a nearby mine had recently closed and residents were concerned about the economic vitality of the town. Thus, most of the testimony coded as economics argued for or against brothels as a draw for business and economic activity. Pro-prostitution testimony supported brothels because they were, in and of themselves, profitable. Such remarks included statements like, "Can we afford, in this time of economic crisis, to put business out of Evenheart?" or, "They never bothered anybody, and they do bring business." Andrew also argued "I have yet to have one tour operator, one person tell me they weren't coming here because of the bordello. The opposite is actually true."

Opponents argued that brothels drove businesses away saying, "New businesses will come in if we rid this town of this evil. Grants and loans will be approved." Other opponents rejected the market logic altogether, saying, "This is not an economic issue, it's not a health issue, it's a moral issue." Some brothel opponents also said that regardless of profitability, brothels drew the wrong kind of people.

Mike: Although brothels bring in tourists, what kind of tourists do they bring in? Now Vegas and Reno have outlawed prostitutions within their city limits, this is for economic reasons. They want to bring in families as tourists who bring in more money.

For brothel opponents, the "right" kinds of consumers were families, families who presumably reflected appropriate heterosexual values, had children, and didn't otherwise consume sex. Mike was echoing the testimony of several brothel opponents who wanted to use government policy to limit the market to these good families. In his closing statements, the city councilman who introduced the ordinance said,

Turnbolt: Mesquite, Nevada. They have one of the hardest sexual oriented business laws on the books, forty pages long, their ordinance. Why? It is because they believe in the family. You have another city, Boulder City. They limit how many families can come into that community. They make sure they get the right family in there. They don't allow drinking except in two places in that town, and they, they don't want industry. Industry is in Las Vegas. They want the family. They're concerned about the family. I think if we, if we want to plan on growing, everybody's talking about economics and tourism and everything else.

They [families] got to have a place to come.

Here, Turnbolt articulated what he felt was his most important argument against the brothels. Brothels needed to be eliminated not just because it was the morally correct thing to do, but also because they needed to bring in the right kind of consumer and the right kind of business. Turnbolt, in this and in other comments said that the "right" kind of consumers were heterosexually appropriate - married, had kids, and did not consume sex (or drink). In this way, opponents deployed market logics in defining "good" consumers and "good" workers who supported the traditionally heterosexual family.

\section{Heteroflexible Workers and Consumers?}

Brothel supporters, on the other hand, drew on market logics to justify sexual businesses as legitimate in ways that were somewhat heteroflexible, and in so doing both reinforced and challenged some heterosexual norms. Using both a free choice morality and a social order discourse, supporters justified brothel businesses as good citizens because, "they don't bother anybody" and because they were profitable. These arguments challenge some heterosexual values - such as the privacy of intimacy, relationship sex, and feminine passive sexuality - for primacy. Additionally, supporters said brothel owners and brothel workers were good, rule following, "law abiding," tax paying citizens.

Christie: I find it rather appalling that you would even consider closing down a business in this town that has an owner that is law abiding and pays their taxes, probably in the manner more timely than some of the residents who are making a big to-do about this issue.

While the sale of sexual services clearly challenges some heterosexual values, supporters did not take this challenge very far. While they supported a public market for sexual intimacy, law-abiding to them simply meant that brothel businesses were not overtly sexual or unduly indecent. Many compared brothels favorably against "the TV and your computer [who] bring all the filth into your house that you could possibly want."

Ben: I've had coffee and beer quite a few times in there. I'll say I've never seen anything indecent, in 
fact I think Cosmopolitan has got better things on its cover.

While brothel workers, i.e. females who publicly traded sex, were seen as legitimate community citizens by brother supporters, hidden in the "they don't bother anybody" rhetoric were also fairly traditional notions of femininity. That brothels and its workers were "good" citizens because they were invisible to the families of the community reflects long time justifications for zoned and regulated prostitution. As one woman commented, "These women do not come and knock on your door and disrupt your family."

Sex workers were also "good" to the extent that they were indistinguishable from the "good" women of town.

Jane: The ladies that come from the so-called red light district of our community, if they walked into your business, had you not been in their business you wouldn't know them from the lady next door.

They were also touted as "good" citizens because they were gender appropriate and responsible consumers.

Susan: They keep their manners on, their verbal manners, and they spend a great deal of money in this community, and I don't think we have the right to tell them that they can't work at the [brothel].

Susan continued on, making clear that that prostitutes, as individuals, were acceptable and legitimate neoliberal citizens because they were self-advancing, self-responsible, and adhered to middle class values.

Susan: They're [women working in the brothels] very intelligent women. They're not deranged people, people that's been sexually abused, druggies, they've got college educations... school teachers in Vegas come up here and work for the summer... There's girls that come up here to earn money to put themselves through college so that they can go on in the profession that they want. Nobody is forcing these girls to come in and do this.

As the above makes clear, important norms of femininity were both reproduced and subverted. Prostitutes had to be appropriately feminine, but women could legitimately sell sexual services. Being sexually active was okay as long as it was in a law abiding, class appropriate business and women were sufficiently self-regulating, self-advancing, and indistinguishable from middle class, family women. It is also important to note that in spite of the fact of their stake in the debate, no female brothel workers testified at this hearing. This further reinforced their legitimacy resting on remaining invisible as sex workers.

Under the market logic used by brothel supporters, there was also room to construct single males as legitimate consumers and sexual desire as a legitimate need of male consumers. While male active sexuality is heteronormative, legitimating sexual desire as a commodity is more heteroflexible in its relationship values. In one visit to Evenheart a month after the hearing, one individuals said to me, "When Turnbolt started talking about families, when he started talking about single men being less good, I said that's me he's talking about. He can't do that." The speaker below ends by saying that brothel consumers "need to go there," and does so in a way that uses market logics to deploy discourses of morality, community, and family.

Jacob: You've got your religious thoughts and beliefs. I respect them. I have my own. But I don't think the city council or anyone else should mandate morals of what this community needs. I raised my family and I did a good job of it, and I'm proud of it. Yet I made my living across the street from a cathouse. The people that go there need to go there.

Other brothel supporters similarly expressed how family values and the sexual needs of men could co-exist. Single men purchasing sex on the market were acceptable, and brothels served a "good function."

Vernon: The brothels serve a good function for singlepeople, men in this community. To have a place that they can go anytime they want to have a little sexual activity, they can go in and know that they're having a place that they can have safe $\operatorname{sex}^{2}$.

While heteroflexible in justifying sexually desiring consumption, the argument that it is okay for males to purchase sex doesn't move male sexual norms far from the sexual double standard that has justified punishing women but not men in legal prostitution cases until fairly recent years. Many of the remarks I coded as gender-related reflected testimony that reinforced norms about men's natural active sex drive. However, there was a difference in the way some supporters deployed a free choice discourse that did not marginalize male sexual consumers, but rather granted their right to consume as representing a moral right and social good. This sits opposite those who used a protectionist rhetoric that cast the male sex drive as potentially dangerous. Several individuals testified that legal brothels are good because they protect families and children by channeling men's sex drive into safe and appropriate spaces. Vernon went on to say,

Vernon: If you guys close the brothels, the single men are not going to quit having sex. They're going to want to continue to have it. If you take away the legal place, they're going to turn to the bars, they're going to turn to the streets. You're going to have an increase in pregnancies, divorces and everything else. If you get a lady downtown [at the local bars], her resistance for an advance is limited. She's more apt to go with somebody, where she wouldn't if she hadn't been drinking.

This protection rhetoric very much reproduced gender norms of active and dangerous male sexuality and passive

\footnotetext{
${ }^{2}$ Female workers in the brothels are subject to weekly tests for various sexually transmitted diseases, and monthly HIV tests. It is this aspect of health and safety, largely for the clients and local families that was discussed in testimony.
} 
females. Referring to comments about the brothels made by customers in her store, a local business owner said,

Sydney: Most of the comments made in my store, was they felt it was a protection, they felt free to move about this community because they weren't looked at by some lecherous person that maybe had unmoral things that they were going to do if they could get these ladies somewhere else.

This discourse articulating male sexuality as potentially dangerous is very similar to post 2000 anti-prostitution protection seeking to protect the sexuality of women and children. This protectionist rhetoric casts those from whom we need protection as potentially not legitimate. Prostitution abolitionists stress the need to protect women's rights from sexually inappropriate men and sexual exploitation (Cronin, 2006; Laite, 2011; Prichard, Kinna, Pinta, \& Berry, 2012; Schwartz, 2010). In contrast to many of today's protectionist arguments, however, brothel supporters used protection discourse to say that legal prostitution $d i d$ protect women and children.

Irene: The clients of these businesses will seek an outlet somewhere. They're going to find it somewhere. Are our high-school and junior high girls safe? Often there are young girls on our streets.

This notion of brothels protecting good female citizens from rape or violence was one echoed in many conversations the author had with citizens in visits to Evenheart, and has been an argument used by brothel owners as well (Brents et al., 2010). A few brothel supporters did refute some of those statements, saying rape was a more complicated issue. This included one city council member who countered the dangers of male lust in her argument against prostitution.

Ellen: There is no way anyone is going to convince me that if the brothels were closed tomorrow that the men of this town would suddenly become mad rapists, it just ain't gonna work folks. There are too many men in this town who are good men.

Not only were single women protected from men by the legal brothels, it was argued, but brothel supporters also used the argument that married women were safer with brothels. In a statement that legitimates non-monogamy and sexual relations outside of marriage, Raina said, "And if it is a married man, at least he's engaging in safe sex and isn't taking some STD home to his family." Vernon went on to say,

Vernon: By closing the houses you take the married man out of the brothels, the ones that are going to cheat on their wives anyhow. They go there for safe sex, so they don't take a disease home to their wife or their unborn child. You take them out of there and put them on the street, the wife and unborn child are the person who's going to suffer for it.

Again, in this excerpt, heteroflexible sexual consumption, even within marriage, is legitimate, challenging norms of monogamy and relationship sex. At the same time, the protectionist rhetoric reinforces heteronormative male active sexuality, and women in need of protection.

Overall, supporters reinforced some conservative gender norms at the same time they subverted a few others, using a market logic. Heteronormative monogamous relationship sex was challenged in that recreational sex, even extramarital sex, was justified under this choice rhetoric, as long as it was safe and confined to the market. Recreational sex in the market was said to be better for women. Female sex workers' active sexual expression was said to be okay as long as they were sufficiently self-advancing. In other words, prostitutes were legitimate citizens. Supporters who drew on free choice discourses to justify active male sexuality reinforced a long standing sexual double standard, but did so in a way that drew on the market as the arbiter of rightness. Those supporters who drew on the rhetoric of protection for non-working women did so in a way that reinforced passive female/active male sexual norms. By serving male sexual urges, brothels protected women and families in the community from sexually predatory males. Using a protectionist discourse defined certain community members as potentially illegitimate if they had "too much" desire. However, it was the free market that would protect.

In addition to the fact that brothel workers themselves did not testify, not a single speaker spoke of the safety, health, or rights of the workers. A great deal of feminist and sex worker rights discourse frames concerns around women's rights to be sexual and to work as sexual beings, but none of this was evident in the hearing. Only the brothel lobbyist mentioned the question of female workers' physical safety. Proponents testified that it was the town's female citizens (not the workers) who were not oppressed due to the existence of the brothels. While sex workers were acceptable citizens to the extent they were appropriately feminine, their rights as workers were never mentioned. The focus of discussion was on the brothel industry and consumers, as well as on the rights of the businesses and consumers, while the topic of brothel worker rights were ignored.

Additionally, while women's rights arguments tend to dominate the brothel debate today, they were notably absent in the Evenheart debates. Opponents of brothels were more likely than supporters to speak of prostitution as a women's issue, saying legal prostitution "degrades women," "increases rape and violence against women" or is "demeaning to women," a frame at least partially consistent with antiprostitution discourses of today. Unlike today's discourses that define prostitutes themselves as victims in need of protection, Evenheart testimony was more oriented to protecting the women outside the brothels than to protecting individual prostitutes. Brothel opponents' point was that prostitution was degrading or demeaning to women in general, and was more much oriented to religious values emphasizing sexual danger than women's rights. Contemporary opposition to prostitution in the oppression frame more explicitly links gender inequality and traditional moral frames in seeking to protect the innocence of women and children involved in prostitution than did the discourses in Evenheart (Kantola \& Squires, 2004; Weitzer, 2009). 


\section{Discussion}

Scholars examining neoliberal sexual politics point to repressive tendencies that support conservative moralities and heteronormative gender, sexual, and relationship values. While these scholars recognize that neoliberal governance is variable and contradictory, we can learn a great deal more by looking at the particular ways in which the logic and discourses in neoliberal governance have been and can be deployed. I find, at least in this small town in Nevada, that neoliberal market logics were deployed in ways that support legal prostitution as well as oppose it. These findings also point to heteroflexibility in neoliberal governance. That is, there is a wide array of heteronormative behaviors, ideologies, and discourses, and while market logics can support some of these, we need to notice those challenges that can undermine the ubiquity of heterosexuality as an institution, particularly those granting rights to previously excluded groups. In this case, key to the depth and form of this challenge is how neoliberal discourses of protection vs. free choice logics are applied. As pointed out in previous research, market logics grant rights only to those deemed sufficiently self-advancing and self-sufficient consumer/citizens, and they certainly undermine collective orientations, or class-based rights.

In many ways, citizens in Evenheart justified and criticized prostitution in ways similar to the past - how prostitution does or does not maintain social order, whether or not it is moral. However, the existence of legal prostitution in the local economy allowed citizens to talk about brothels as businesses, adding an additional market element to the debate that is missing in some debates today. This allowed individuals testifying to deploy market logics through discourses of family values and morality, not just in discussing the economic advantages of brothels. Opponents upheld heteronormative family values in defining legitimate sexual consumers and businesses, and otherwise used a conservative morality to oppose commercial sex. Brothel supporters deployed a market logic that defined a market morality and family values in ways that highlighted individual free choice and responsibility, upholding heteroflexible sexual tolerance to legitimate a sexually desiring citizen/consumer and granting citizenship rights to female prostitutes. Supporters upheld a radically individuated set of values much different than the collective values on which social order and moral discourses have historically rested.

Citizens on both sides of the debate also used protectionist discourses foreshadowing anti-prostitution debates today. To the extent supporters and opponents drew on discourses of protection, they were more likely to reproduce heterosexual notions of the traditional family form, males as sexually active, and female sexual passivity. Protectionist discourses also rest on defining illegitimate "others" in ways that free choice discourse may not.

Gail Hawkes argues that the key to a profound challenge to heterosexual orthodoxy is dismantling the gender binary (Hawkes, 1996). How significant were the challenges in Evenheart? The discourses did not challenge masculine active sexuality or feminine passive sexuality in citizens or consumers. There was support of active sexuality for female sex workers challenging the binary dividing women from active male sexuality, but at the same time, female sex workers were still held accountable to other feminine values. There was also no mention of same sex desire, gender bending, BDSM or fetishes, all practices that are part of brothel services (Brents et al., 2010). Addtiionally, the notion of the asexual child was very clearly reinforced in the calls for family values.

Nevertheless, testimony in support of prostitution offered some challenges to the array of norms that have contributed to heterosexuality's dominance:

- Acceptance of sexual pleasure as a marketable commodity

- Weakening the public/private divide and accepting intimacy in the marketplace

- Accepting non-monogamy and multiple sex partners in the market

- Women's right to participate as sex workers in the public sexual marketplace.

- Slight convergence in the active/passive sexuality divide among genders

- Children can co-exist in a sexual marketplace, with appropriately responsible parents

Rather than theorize only the sexual limits of neoliberal governance, or look only at its heteronormativity, Hawkes challenges us to consider the wide variety of elements that have built heterosexual dominance in industrial capitalism. This study finds that market logics can be deployed in ways that challenge some but reproduce other of those elements. That a heteroflexibility has (re-)appeared in neoliberal culture is not just heterosexuality made more resilient, but perhaps signals that the short-lived dominance of heterosexuality in industrial capitalism is shifting in today's neoliberal culture. Market logics encourage tolerance in market exchanges, elevating sexual desire and its fulfillment as a right, under certain conditions. The self-advancing citizen is also a citizen that can fulfill sexual desires in a range of ever-expanding options. Though in this case that freedom did not expand discourse to include same sex desire, it certainly expanded discourse on recreational sexual desire. It is these expanding boundaries of desire upon which citizenship extends in late capitalist neoliberal governance. Expanding boundaries around social class, economic inequality, or worker rights remained outside the scope of discourse.

\section{Conclusions}

This case study analyzed prostitution debates in a unique setting where prostitution is already legal, and thus has limited generalizability. Citizens were able to discuss brothels as existing players in the market, making it easier to deploy market logics to prostitution. That said, it is clear that market logics were able to be deployed in a variety of ways by both opponents and supporters of legalized brothels. We need more research on the variety of neoliberal discourses, including free choice and protectionist, and how these are 
deployed along with other discourses of morality, sexuality, and gender in other settings.

Gender and sexually conservative policies do not seem an inevitable outcome within neoliberal governance. Duggan and others argue that by granting rights only to those who are appropriately coupled and consuming, neoliberalism fragments movements for social change (Duggan, 2004). This research finds more complexity in how these discourses operate, with free choice discourses and market morality potentially expanding tolerance and rights in ways that protectionist discourses do not. Using free choice and market morality discourses, sexual and gender rights movements may have an opportunity to push policies that extend citizenship to excluded groups and expand the circle of acceptable sexual expression. Sex worker rights groups must take care not to exclude less privileged groups within this rhetoric, which means they must try and use labor rights discourses alongside free choice discourses when possible (Brents \& Hausbeck, 2010; C. A. Jackson, 2016). Public testimony in Evenheart provides an important glimpse into the ways in which neoliberal modes of citizenship and market logics ran consistent with support for prostitution. Formal alternatives to criminalizing prostitution can be deemed acceptable as long as citizens see that business as supporting community values, as protecting consuming citizens, and as involving selfadvancing consumers and service providers. What seems far less possible within these neoliberal logics, is the articulation of class-based or collective worker rights. Certainly neoliberal policies have been antithetical to unions and collective bargaining and protectionist policies are oriented to protecting the middle class (Bartels, 2009; Clawson \& Clawson, 1999; Harvey, 2007; Wacquant, 2009). Even free choice and market moralities remain primarily focused on the worker as an individual, and it is difficult to articulate collective labor rights within that framework (C. A. Jackson, 2016).

Prostitution policies, as with any social policy, are subject to a variety of political forces. As noted above, this late 1990s debate took place just as prostitution discourses were changing. These changes reflected a shift in the political opportunities afforded by a conservative presidential administration and successful organizing by a coalition of religious right evangelical organizations and radical antiprostitution feminists. More research needs to be done on the specific ways in which local politics, social movement actions, political access, and resources matter in the production of broader cultural discourses of sexuality.

Acknowledgements I would like to thank Georgiann Davis and Ranita Ray for very helpful comments, and especially Kate Hausbeck Korgan without whom this research would not have been possible.

Compliance with Ethical Standards All procedures performed in studies involving human participants were in accordance with the ethical standards of the institutional and/or national research committee and with the 1964 Helsinki declaration and its later amendments or comparable ethical standards. Informed consent was not required and therefore not obtained as information was gathered from public records and observations in public forums.

\section{References}

Ambrose, E. (2009). Heteroflexibility: bending the existing label triangle. Journal of Student Affairs, 18, 69-75.

Attwood, F. (2006). Sexed Up: Theorizing the Sexualization of Culture. Sexualities, 9(1), 77-94.

Bartels, L. M. (2009). Unequal democracy: The political economy of the new gilded age: Princeton University Press.

Bauman, Z. (2000). Liquid modernity. Cambridge, UK: Polity Press.

Bauman, Z. (2003). Liquid love: on the frailty of human bonds. Malden, MA: Blackwell Publishers.

Bay-Cheng, L. Y. (2015). The agency line: A neoliberal metric for appraising young women's sexuality. Sex roles, 1-13.

Bedford, K. (2009). Developing partnerships : gender, sexuality, and the reformed World Bank. Minneapolis: University of Minnesota Press.

Bernstein, E. (2001). The meaning of the purchase: Desire, demand and the commerce of sex. Ethnography, 2(3), $389-420$.

Bernstein, E. (2007a). The Sexual Politics of the" New Abolitionism". differences, 18(3), 128-151.

Bernstein, E. (2007b). Temporarily Yours: Intimacy, Authenticity and the Commerce of Sex. Chicago: University of Chicago Press.

Bernstein, E. (2012). Carceral politics as gender justice? The "traffic in women" and neoliberal circuits of crime, sex, and rights. Theory and Society, 41(3), 233-259.

Bernstein, E., \& Jakobsen, J. R. (2010). Sex, secularism and religious influence in US politics. Third world quarterly, 31(6), 1023-1039.

Best, J. (1998). Controlling vice : regulating brothel prostitution in St. Paul, 1865-1883. Columbus: Ohio State University Press.

Bowers, M. W. (1996). The Sagebrush State : Nevada's history, government, and politics. Reno: University of Nevada Press.

Brenner, N., Peck, J., \& Theodore, N. (2010). After neoliberalization? Globalizations, 7(3), 327-345.

Brents, B. G., \& Hausbeck, K. (2001). State Sanctioned Sex: Negotiating Informal and Formal Regulatory Practices in Nevada Brothels. Sociological Perspectives, 44(3), 307-332.

Brents, B. G., \& Hausbeck, K. (2010). Sex Work Now: What the blurring boundaries around the sex industry means for sex work, research and activism. In M. Ditmore, A. Levy, \& A. Willman (Eds.), Sex Work Matters: Exploring Money, Power and Intimacy in the Global Sex Industry. London: Zed Books.

Brents, B. G., Jackson, C., \& Hausbeck, K. (2010). The State of Sex: Tourism, Sex and Sin in the New American Heartland. New York: Routledge.

Brents, B. G., \& Sanders, T. (2010). Mainstreaming the sex industry: Economic inclusion and social 
ambivalence. Journal of Law and Society, 37(1), 4060.

Brents, B. G., \& Sanders, T. (2016 (in press)). The 'Victim and Offender and Discourse' in the debates and policy on prostitution and sex work. In B. Francis \& T. Sanders (Eds.), Oxford Handbook of Sex Offences and Sex Offenders. New York: Oxford University Press.

Burke, K. (2014). What makes a man: Gender and sexual boundaries on evangelical Christian sexuality websites. Sexualities, 17(1-2), 3-22.

Butler, J. (2008). Sexual politics, torture, and secular time. The British journal of sociology, 59(1), 1-23.

Cao, L., Lu, R., \& Mei, X. (2015). Acceptance of prostitution and its social determinants in Canada. International Journal of Offender Therapy and Comparative Criminology, 0306624X15609920.

Cao, L., \& Maguire, E. R. (2013). A Test of the Temperance Hypothesis: Class, Religiosity, and Tolerance of Prostitution. Social Problems, 60(2), 188-205.

Chapkis, W. (2003). Trafficking, Migration, and the Law: Protecting Innocents, Punishing Immigrants. Gender and Society, 17(6), 923-937.

Cheng, S., \& Kim, E. (2014). The Paradoxes of Neoliberalism: Migrant Korean Sex Workers in the United States and "Sex Trafficking". Social Politics: International Studies in Gender, State \& Society, 21(3), 355-381.

Clawson, D., \& Clawson, M. A. (1999). What has happened to the US labor movement? Union decline and renewal. Annual Review of Sociology, 25, 95-119.

Coalition Against Trafficking in Women. $(2011,2011)$. Who Are We--History. Retrieved from http://www.catwinternational.org/WhoWeAre/Histor $\mathrm{y}$

Comella, L. (2012). Changing the World One Orgasm at a Time: Sex Positive Retail Activism. In R. Mukherjee \& S. Banet-Weiser (Eds.), Commodity Activism: Cultural Resistance in Neoliberal Times (pp. 240253). New York: New York University Press.

Cronin, M. M. (2006). The Liberty to Argue Freely: Nineteenth-Century Obscenity Prosecutions and the Emergence of Modern Libertarian Free Speech Discourse. Journalism \& Communication Monographs, 8(3), 163-219.

Duggan, L. (2004). The twilight of equality?: Neoliberalism, cultural politics, and the attack on democracy. Boston: Beacon Press.

Elliott, S. (2014). "Who's to Blame?" Constructing the Responsible Sexual Agent in Neoliberal Sex Education. Sexuality Research and Social Policy, 11(3), 211-224.

Ferguson, R. A. (2012). The reorder of things: The university and its pedagogies of minority difference. Minneapolis: University of Minnesota Press.

Foucault, M. (1978). The history of sexuality, vol 1: an introduction (R. Hurley, Trans. 1st American ed. Vol. 1). New York: Pantheon Books.
Frohard-Dourlent, H. (2012). When the heterosexual script goes flexible: Public reactions to female heteroflexibility in the Buffy the Vampire Slayer comic books. Sexualities, 15(5-6), 718-738.

Gilfoyle, T. J. (1992). City of Eros : New York City, prostitution, and the commercialization of sex, 17901920 (1st ed.). New York, N.Y.: W.W. Norton.

Grzanka, P. R., \& Maher, J. (2012). Different, Like Everyone Else: Stuff White People Like and the Marketplace of Diversity. Symbolic Interaction, 35(3), 368-393.

Grzanka, P. R., \& Mann, E. S. (2014). Queer youth suicide and the psychopolitics of "It Gets Better". Sexualities, 17(4), 369-393.

Harvey, D. (1989). The condition of postmodernity: an enquiry into the origins of cultural change. Oxford [England] ; Cambridge, Mass., USA: Blackwell.

Harvey, D. (2007). A brief history of neoliberalism: Oxford University Press, USA.

Hausbeck, K., \& Brents, B. G. (2009a). Inside Nevada's Brothel Industry. In R. Weitzer (Ed.), Sex for Sale (2nd ed., pp. 314-343). New York: Routledge.

Hausbeck, K., \& Brents, B. G. (2009b). McDonaldization of the Sex Industries? The Business of Sex. In G. Ritzer (Ed.), McDonaldization: the reader (3rd ed., pp. 102118). Thousand Oaks, Calif.: Pine Forge Press.

Hawkes, G. (1996). A sociology of sex and sexuality. Philadelphia: Open University Press.

Heath, M. (2012). One marriage under God: The campaign to promote marriage in America: NYU Press.

Heath, M. (2013). Sexual misgivings: producing un/marked knowledge in neoliberal marriage promotion policies. The Sociological Quarterly, 54(4), 561-583.

Hennigan, P. C. (2004). Property war: Prostitution, red-light districts, and the transformation of public nuisance law in the Progressive Era. Yale JL \& Human., 16, 123.

Illouz, E. (1997). Consuming the romantic utopia: love and the cultural contradictions of capitalism. Berkeley: University of California Press.

Inglehart, R. (1990). Culture shift in advanced industrial society. Princeton, N.J.: Princeton University Press.

Inglehart, R. (1997). Modernization and postmodernization: cultural, economic, and political change in 43 societies. Princeton, N.J.: Princeton University Press.

Inglehart, R. (2008). Changing Values among Western Publics from 1970 to 2006. Western European Politics, 31(12), $130-146$.

Inglehart, R., \& Norris, P. (2003). Rising tide: Gender equality and cultural change around the world. New York: Cambridge University Press.

Jackson, C. A. (2016). Framing Sex Worker Rights How US Sex Worker Rights Activists Perceive and Respond to Mainstream Anti-Sex Trafficking Advocacy. Sociological Perspectives, 59(1), 27-45.

Jackson, S., \& Scott, S. (2004). Sexual Antinomies in Late Modernity. Sexualities, 7(2), 233-248. 
Kantola, J., \& Squires, J. (2004). Discourses surrounding prostitution policies in the UK. European Journal of Women's Studies, 11(1), 77-101.

Katz, J. N. (2014). The invention of heterosexuality: University of Chicago Press.

Kelly, P. (2008). Lydia's open door : inside Mexico's most modern brothel. Berkeley: University of California Press.

Kempadoo, K. (2005). From moral panic to global justice: Changing perspectives on trafficking. In $\mathrm{K}$. Kempadoo (Ed.), Trafficking and prostitution reconsidered: New perspectives on migration, sex work, and human rights (pp. 3-24). Boulder: Paradigm.

Laite, J. (2011). Common prostitutes and ordinary citizens: commercial sex in London, 1885-1960: Palgrave Macmillan.

Lakkimsetti, C. (2014). "HIV Is Our Friend": Prostitution, Biopower, and the State in Postcolonial India. Signs, 40(1), 201-226.

Lemke, T. (2001). 'The birth of bio-politics': Michel Foucault's lecture at the Collège de France on neo-liberal governmentality. Economy and society, 30(2), 190207.

Lerum, K., \& Brents, B. G. (2016). Sociological Perspectives on Sex Work and Human Trafficking. Sociological Perspectives, 59(1), 17-26.

Lucas, A. M. (1995). Race, class, gender, and deviancy: The criminalization of prostitution. Berkeley Women's LJ, $10,47$.

Luker, K. (1998). Sex, Social Hygiene, and the State: The Double-Edged Sword of Social Reform. Theory and Society, 27(5), 601-634.

Miller, P., Gordon, C., \& Burchell, G. (1991). The Foucault effect: studies in governmentality. Chicago: University of Chicago Press.

Moehring, E. P. (2000). Resort city in the sunbelt : Las Vegas, 1930-2000 (2nd ed.). Reno: University of Nevada Press.

Ong, A. (2006). Neoliberalism as exception: Mutations in citizenship and sovereignty: Duke University Press.

Outshoorn, J. (2001). Debating Prostitution in Parliament A Feminist Analysis. European Journal of Women's Studies, 8(4), 472-490.

Outshoorn, J. (2004). The politics of prostitution : women's movements, democratic states, and the globalisation of sex commerce. Cambridge, UK ; New York: Cambridge University Press.

Peck, J., Theodore, N., \& Brenner, N. (2010). Postneoliberalism and its malcontents. Antipode, 41(s1), 94-116.

Peck, J., \& Tickell, A. (2002). Neoliberalizing space. Antipode, 34(3), 380-404.

Pettinger, L. (2013). Market moralities in the field of commercial sex. Journal of Cultural Economy, 6(2), 184-199.
Plummer, K. (2003). Intimate citizenship : private decisions and public dialogues. Seattle: University of Washington Press.

Prasad, M. (1999). The Morality of market exchange: Love, money, and contractual justice. Sociological Perspectives, 42(2), 181-214.

Prichard, A., Kinna, R., Pinta, S., \& Berry, D. (Eds.). (2012). Libertarian socialism: politics in black and red. New York: Palgrave Macmillan.

Read, K. W. (2013). Queering the brothel: Identity construction and performance in Carson City, Nevada. Sexualities, 16(3-4), 467-486.

Rivers-Moore, M. (2014). Waiting for the State: Sex Work and the Neoliberal Governance of Sexuality. Social Politics: International Studies in Gender, State \& Society, jxu020.

Rofel, L. (2007). Desiring China: experiments in neoliberalism, sexuality, and public culture. Durham, NC: Duke Univ Press.

Rubin, G. (1984). Thinking Sex. Notes for a Radical theory on the politics of sexuality. In C. S. Vance (Ed.), Pleasure and Danger: Exploring Female Sexuality (pp. 267-319). London: Routledge.

Sanders, T., \& Campbell, R. (2014). Criminalization, protection and rights: Global tensions in the governance of commercial sex. Criminology and Criminal Justice, 14(5), 535-548.

Schwartz, L. (2010). Freethought, Free Love and Feminism: secularist debates on marriage and sexual morality, England c. 1850-1885. Women's history review, 19(5), 775-793.

Shamir, R. (2008). The age of responsibilization: On marketembedded morality. Economy and society, 37(1), 119.

Soss, J., Fording, R. C., \& Schram, S. (2011). Disciplining the poor: Neoliberal paternalism and the persistent power of race: University of Chicago Press.

Sparke, M. B. (2006). A neoliberal nexus: Economy, security and the biopolitics of citizenship on the border. Political geography, 25(2), 151-180.

Stack, S., Adamczyk, A., \& Cao, L. (2010). Survivalism and public opinion on criminality: A cross-national analysis of prostitution. Social Forces, 88(4), 17031726 .

Symons, K., \& Gillis, K. (2014). Talking about prostitution and the representation of a (problematic) group: Identifying frames in Flemish news coverage on prostitution. In N. Peršak, Vermeulen, G eds (Ed.), Reframing Prostitution: From Discourse to Description, From Moralisation to Normalisation (pp. 121-143). Portland: Maklu.

Wacquant, L. (2009). Punishing the poor: The neoliberal government of social insecurity: Duke University Press.

Weitzer, R. (2007). The Social Construction of Sex Trafficking: Ideology and Institutionalization of a Moral Crusade. Politics and Society, 35(3), 447-475. 
Weitzer, R. (2009). Legalizing prostitution: Morality Politics in Western Australia. British Journal of Criminology, 49, 88-105.

Weitzer, R. (2011). Legalizing Prostitution: From Illicit Vice to Lawful Business. New York: New York University Press.

Weitzer, R. (2015). Researching prostitution and sex trafficking comparatively. Sexuality Research and Social Policy, 12(2), 81-91.

White, K. (1993). The first sexual revolution: The emergence of male heterosexuality in modern America (Vol. 27): NYU Press.

Wilson, K. (2015). Towards a Radical Re - appropriation: Gender, Development and Neoliberal Feminism. Development and Change, 46(4), 803-832.

Wonders, N. A., \& Michalowski, R. (2001). Bodies, Borders, and sex tourism in a globalized world: A tale of two cities -- Amsterdam and Havana. Social Problems, 48(4), 545-571.

Zelizer, V. A. R. (2005). The purchase of intimacy. Princeton, NJ: Princeton University Press. 